\title{
Civill Engineering \\ Study of the \\ interaction of concrete walls with the foundation structure
}

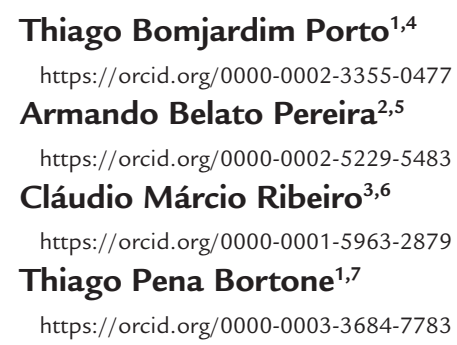

Antônio Ribeiro de Oliveira Neto ${ }^{1,8}$

https://orcid.org/0000-0001-9050-4621

${ }^{1}$ Centro Federal de Educação Tecnológica de Minas Gerais - CEFET-MG, Departamento de Engenharia Civil e Meio Ambiente,

Curvelo - Minas Gerais - Brasil.

${ }^{2}$ Centro Federal de Educação Tecnológica de Minas Gerais - CEFET-MG, Departamento de Computação e Engenharia Civil,

Varginha - Minas Gerais - Brasil.

${ }^{3}$ Thema Engenharia Projetos e Sistemas Ltda., Departamento Técnico de Engenharia Civil, Belo Horizonte - Minas Gerais - Brasil.

E-mails: ${ }^{4}$ thiago.porto@cefetmg.br,

5armandobelato@cefetmg.br,

${ }^{6} \mathrm{cmr7solucaoestrutura|@gmail.com}$,

7thiago.bortone@cefetmg.br,

santonioribeiro@cefetmg.br

\begin{abstract}
This article presents a study of the factors that influence the mechanism of soil-structure interaction with a pilot building having concrete walls and their impact on their performance. To illustrate the studies carried out, a numerical modeling of a four-floor concrete wall pilot building was performed, subjected to vertical actions, supported by a slab-on-ground foundation, using the Finite Element Method (FEM), together with specific 3D software for analysis and structural dimensioning in reinforced concrete. For the consideration of the geotechnical and structural system (foundation structure), the discrete spring model (Winkler model) coupled to the superstructure was used and the slab foundation thickness was varied by $16 \mathrm{~cm}$, $25 \mathrm{~cm}$ and $40 \mathrm{~cm}$. The local geotechnical formation was represented by a soft clay $(\mathrm{SPT}=5)$ from the Belo Horizonte Metropolitan Region, Brazil. The influential factors of the SSI analyzed in this research were: relative stiffness of the foundation structure, requesting stresses, settlements in the foundation of the building and steel reinforcement bar ratio. For a better visualization of the influence of these various factors, an analysis was made of the distribution of normal stresses and stresses at the base of the walls of this building, in the form of graphs. Finally, it was concluded that the change in slab foundation, stiffness influences the distribution of stresses and stresses in the foundation, with a tendency to uniformity as the slab foundation thickness increases. However, this relationship is not linear.
\end{abstract}

Keywords: structural analysis, concrete walls, numerical modeling, soil structure interaction, foundations.

\section{Introduction}

In recent years, the search for alternatives to ensure more rational and sustainable engineering solutions has grown considerably. At the time when the first Brazilian standard on dimensioning and execution of reinforced concrete structures, the NB-1 (ABNT, 1940), was published, all studies were done in an analytical (manual) and simplified way, otherwise there would be no time for the elaboration of structural and foundation designs. Since Brazil was going through several phases of successive economic growth, the so-called "economic miracle", with emphasis on the construction of the new national capital, Brasília and construction of the Rio de Janeiro and São Paulo subway. These calculations, most of the times assumed that the structure under analysis behaved in a linear manner (physically and geometrically), which unfortunately brought with it a structural oversizing. Over the years, with the advancement of information technology, and of course the numerical models that represent the superstructure and infrastructure of a civil enterprise, more rigorous and, sometimes more economical, analyses have been made possible, enabling the civil construction entrepreneur to conceive structures more trustworthy with reality.

In this context, one of the biggest challenges for project management engi- 
neers was to unify the geotechnical and structural analyzes of a study building. Since the 1940s, specialists have worked independently (autonomously), disregarding, therefore, the interaction between the interfaces of the disciplines. The calculator considered the building supports to be rigid, therefore, inextricable and the geotechnical considered a constant characteristic load on the foundation per pillar, and therefore, without a joint approach of rigidity, thus neglecting the solidarity of the building's repression and naturally

\section{Concrete walls structural system}

Among the main rationalized construction systems used in Brazil, the following stand out: structural masonry, reinforced concrete, steel frame, wood frame and concrete walls. The 80 s and 90 s were marked by the use of structural masonry as an alternative to fill the existing housing deficit in the country, mainly from families that received up to 3 minimum monthly wages, Porto (2010). There were buildings with 4 (four) floors, usually without a covered garage, financed by government programs through Caixa Econômica Federal (CAIXA). At the time, the construction of buildings without the need for columns and beams (self-supporting structure) became an excellent alternative to popular constructions on a large scale.

With the creation of the Programa de Aceleração do Crescimento (PAC) by the federal government in the 2000s, inspired by successful experiences in Latin American countries such as Chile, Colombia and Mexico, Carvalho (2012), there was a favorable environment for the implementation of a new construction system in the country, called "Concrete Walls". Conceptually, reinforced concrete columns are predominantly elements subject to compression actions that have the largest side (h) less than 5 (five) times the smallest (b), Assis and Porto (2019). When this condition is not met, the pillar is no longer a bar element and is treated as a shell or plate element, subject to

\section{Soil-structure interaction (SSI)}

The consideration of the superstructure of buildings supported by fixed supports, therefore, inextricable is no longer acceptable in the academic and professional environment. According to Sing and Jha (2014, p. 2124), "the complexity in the behavior of soil has a redistribution of the building's actions.

Within the scope of the joint numerical analysis (equivalent) of the structural and geotechnical system in the elaboration of engineering designs, the current versions of NBR 6122 (ABNT, 2019) and NBR 6118 (ABNT, 2014) provide for consideration of the soil-structure interaction (ISE) in designs. The application of ISE, although new in the design of buildings (superstructure and foundation), was already widely used in the 1970s and 1980s in the design of special works of art

flexion outside its plane, Fernandes and Porto (2015). Until 2012, there was no standard in Brazil that specifically dealt witht thin-walled columns. Due to this absence, driven mainly by national economic growth, the Associação Brasileira de Normas Técnicas (ABNT) created NBR 16055 (2012) to establish the basic requirements for the development of designs on concrete walls molded in loco for the construction of buildings. This standard establishes the necessary procedures for the design, structural analysis, dimensioning and detailing of concrete walls. Regarding ISE in the analysis of buildings having concrete walls up to 5 (five) floors, NBR 16055 requires that this consideration be incorporated. As for detailing, the frames are made by screens and reinforcements (regions of stress concentrations) that are used in places of openings, such as doors and windows. For buildings with up to 6 floors, the walls are usually $10 \mathrm{~cm}$ with a screen frame in the geometric center of the wall. For tall buildings, whose wind action is significant, the walls are $15 \mathrm{~cm}$ thickness and have a double screen frame, Farias (2018).

As in structural designs, in structural masonry, the descent of vertical loads in buildings with concrete walls is done in the calculation offices using the criterion of a group of isolated walls, Testoni (2013). Although the pioneering use of the concrete walls construction system is a merit

led the development of many models of soil based on classical theory of elasticity, plasticity and visco-elasticity for the analysis of soil-structure interaction problems". Nowadays, most technicalscientific commercial software have in their package a module of Soil-Structure and civil structures subject to dynamic actions, as shown by Porto, Mendonça and Carvalho (2012).

This article aims to contribute to the understanding of ISE in the building of concrete walls supported on superficial foundations of the slab-on-ground type on low capacity support soils, demonstrating the importance of this consideration in the development of structural designs and of rational and safe foundations based on a case study presented by Ribeiro (2017).

of popular works applied to buildings with up to 6 floors, the use of this technology in tall buildings is growing every day as a target audience for middle class families.

Academically, numerical studies related to the structural system of concrete walls are made considering the walls as shell elements, and the modeling is currently done using the Finite Element Method (FEM). Due to the slowness to operationalize such verification in the day-to-day of structural designers, these analyses are routinely made using the Three-dimensional Gantry Method, where it transforms the flat element (wall) into a bar element with equivalent inertia, simplifying and speeding up the calculation procedures.

Testoni and Correa (2016) highlight that the study of soil-structure interaction in buildings with concrete walls is a little explored topic in the technical literature that deserves the attention of researchers and designers of this type of structure. In order to elucidate any questions regarding the exposed procedure, Braguim and Bittencourt (2014) present a case study, where, by comparing the maximum normal compression stress, a numerical model in MEF and another in MPT was made for a 15 -floor building 15 floors with concrete walls. The results show differences of less than $5 \%$ in the normal tension values in the walls, thus validating the simplified model in question.

Interaction (SSI), thus facilitating the design of structures more consistent with reality. The level of accuracy of the analysis, however, depends on the user experience and the models available for the study. As will be seen in the following topics, trivial models represent the 
soil as a set of linearly spaced springs, respecting Hooke's law, therefore, a linear elastic regime, Figure 1. Other models assume the terrain as non-linear springs, which depending on the tension level, can work with the assumption that the geotechnical massif is elastic or plastic. More elaborate models consider the soil as a continuous stratified, heterogeneous and anisotropic medium, thus representing the behavior of the massif in greater detail, Figure 2.

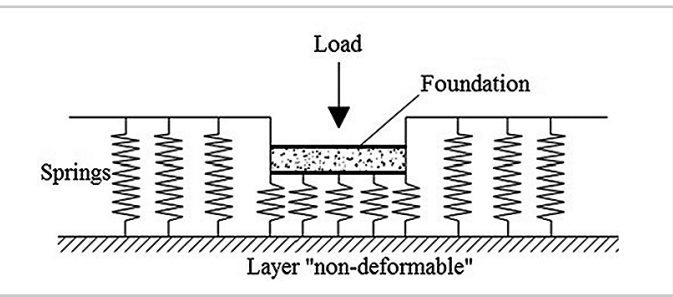

Figure 1 - Winkler Hypothesis: deformability of the soil by means of discrete springs (Antoniazzi, 2011).

Even with the evolution in computational resources, the modeling of the geotechnical massif remains a challenge for professionals in the area, since the soil is often made up of materials of different natures (organic matter, landfill, clay, silt, sand, boulder) with different strengths, for example, with decreasing load capacity with depth, while the ground resistance is expected to increase with depth. Thus, the best way to characterize the soil properly

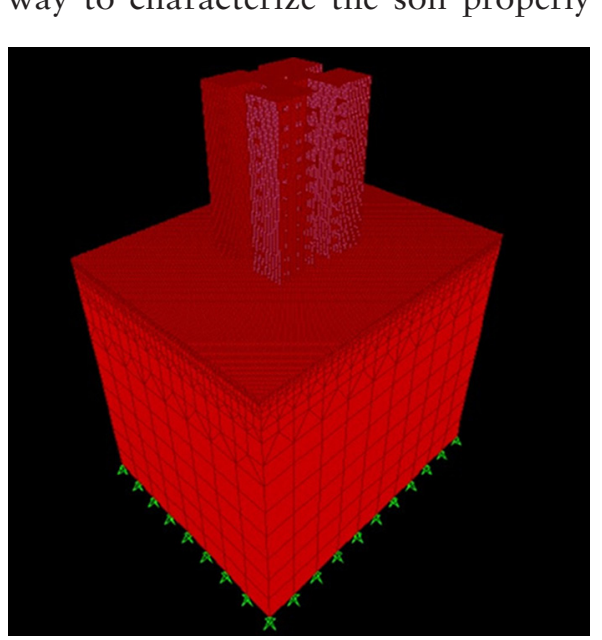

is with the use of a load test. In Brazil, this test is regulated by NBR 6489 (ABNT, 2019). This Standard establishes the general conditions to be met in load tests on land, for the purpose of shallow foundations.

Figure 2 - Modeling of the geotechnical system as a continuous medium (Porto and Silva, 2011).

According to Siqueira (2019), among the classic models to consider SSI in geotechnical designs, the most used currently are those in which the soil deformability can be represented by means of elastic springs or not in the structure-soil interface, where the properties of the massif are considered (Poisson's ratio, longitudinal and transversal modulus of elasticity) and the compatibility of the settlements. Within the models presented in literature, we can mention the models of FilonenkoBorodic, Pasternak, Kerr and Horvth, with details for the Winkler model, which is widely disseminated.

Winkler's theory, initially proposed in 1867, by the German engineer Emil Winkler assumes that the soil can be represented by linearly spaced springs that respect Hooke's law, therefore, a linear elastic regime, Figure 3.

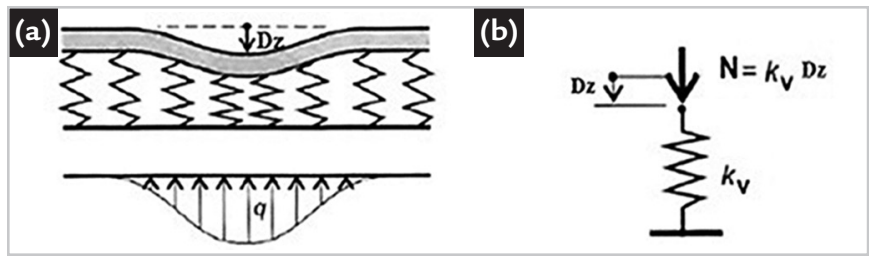

Figure 3 - Schematic representation of the Winkler model (Velloso and Lopes, 2010).

In this model, the contact pressures are proportional to the settlements. Mathematically, we have:

$$
N=K_{V} \cdot D_{Z}
$$

Where:

$\mathrm{N}=$ force;

$K_{v}=$ Proportionality constant, vertical reaction coefficient or spring coefficient;

$\mathrm{D}_{\mathrm{z}}=$ vertical displacement (settlement). 


\section{Case study}

The pilot building for this work has 4 floors with a projection area of $208.86 \mathrm{~m}^{2}$, illustrated in Figure 4. It is a building whose architectural features fit the Federal Government's "Minha Casa Minha Vida" pattern. The walls and slabs are 10 (ten) $\mathrm{cm}$ thick and the floor covering is insulated (without access to the public), with a ceramic roof covering all apartments. The garage is external to the building and the type of ground floor (pilotis) is similar to the standard floor, except for an apartment adapted for people with special needs. Each block has two equal modules, separated by an expansion joint. For this article, a single module will be studied, with its results assumed to be constant and representative for the block, Figure 5.

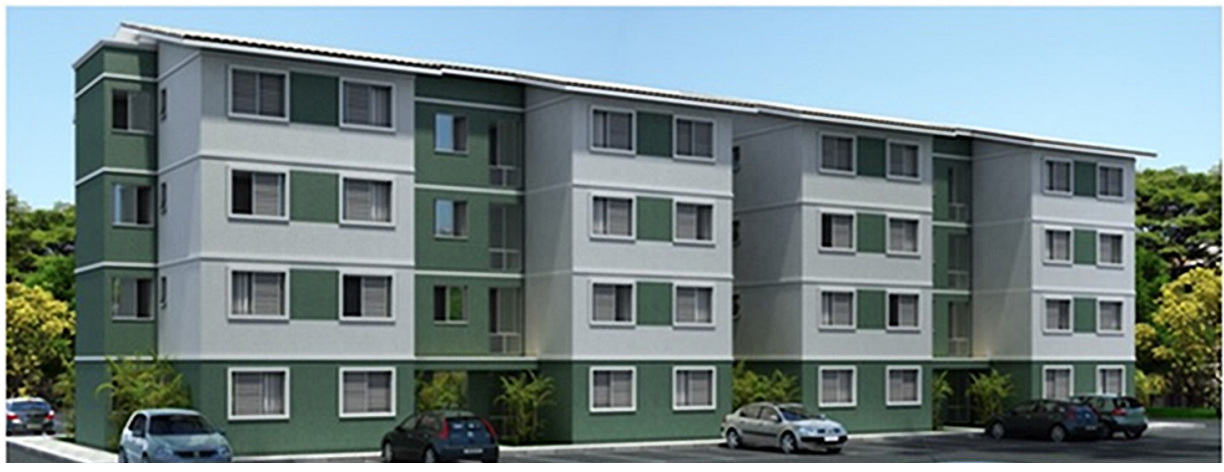

Figure 4 - Pilot building with concrete walls.

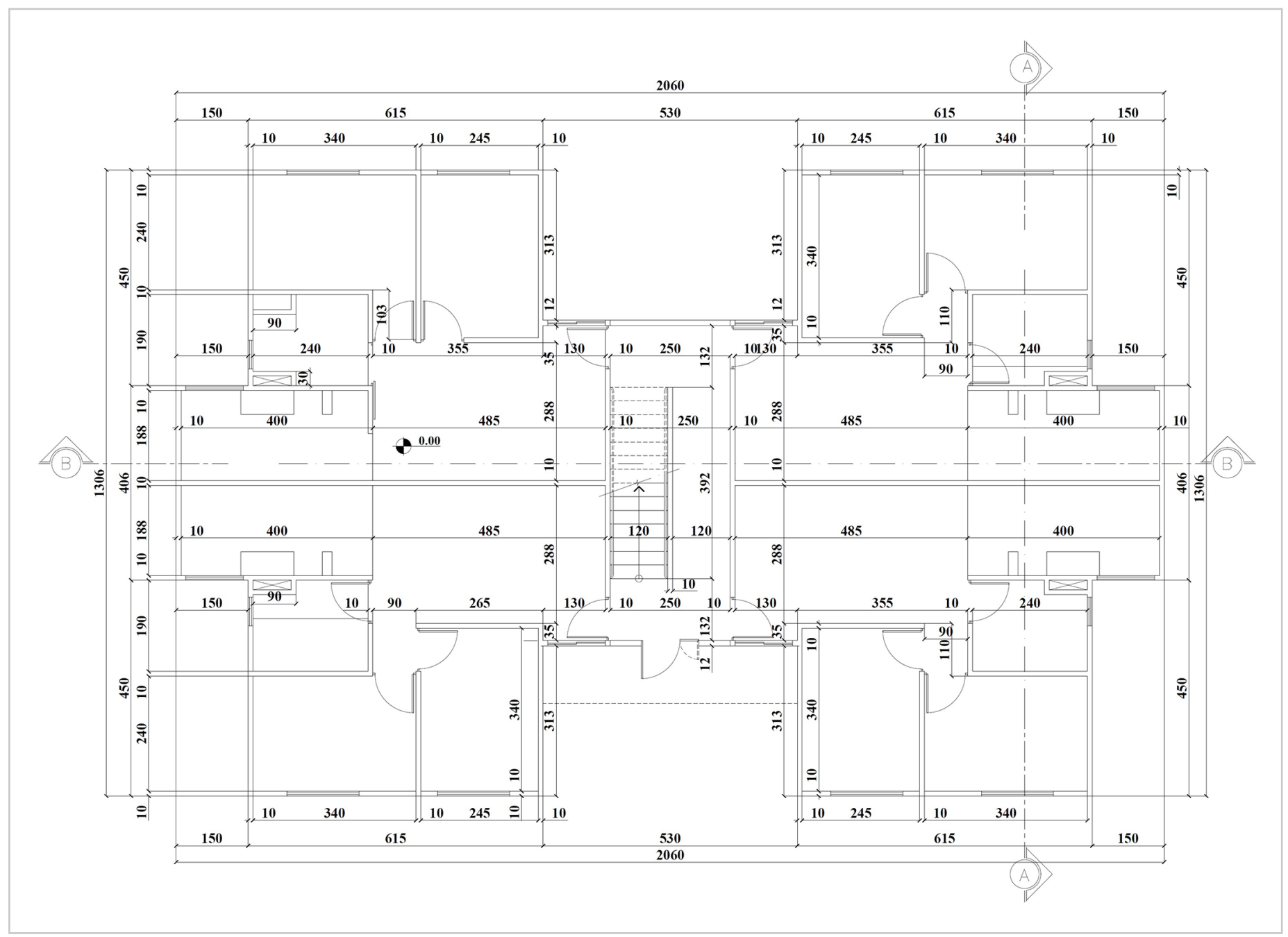

Figure 5 - Floor plan of the pilot building (floor type).

The pilot building was considered to have characteristic compressive strength $f_{c k}=25 \mathrm{MPa}$, with environmental aggressiveness class equal to II (NBR 6118/2014), Poisson's ratio $v=0.20$, elastic modulus $E=23,800$ $\mathrm{MPa}$ and specific weight $\gamma_{c}=25 \mathrm{kN} / \mathrm{m}^{3}$. CA-50 and CA-60 steels were used, with respective $f_{y}$ yield stresses (characteristic stresses) equal to $500 \mathrm{MPa}$ and $600 \mathrm{MPa}$.

The foundation assumed for research was shallow, in slab-onground, $120 \mathrm{~cm}$ away from the external faces of the building, Figure 6 . 
Considered was a soil with low support capacity $(\mathrm{SPT}=5$ and allowable stress $\left.=1 \mathrm{kgf} / \mathrm{cm}^{2}\right)$ with clay char- acteristics (unsaturated) throughout the building projection. The vertical reaction coefficient adopted, $\mathrm{K}_{v}$, was
$22,000 \mathrm{kN} / \mathrm{m}^{3}$, value consistent with the technical literature, e.g., Moraes (1981) and Morrison (1993).

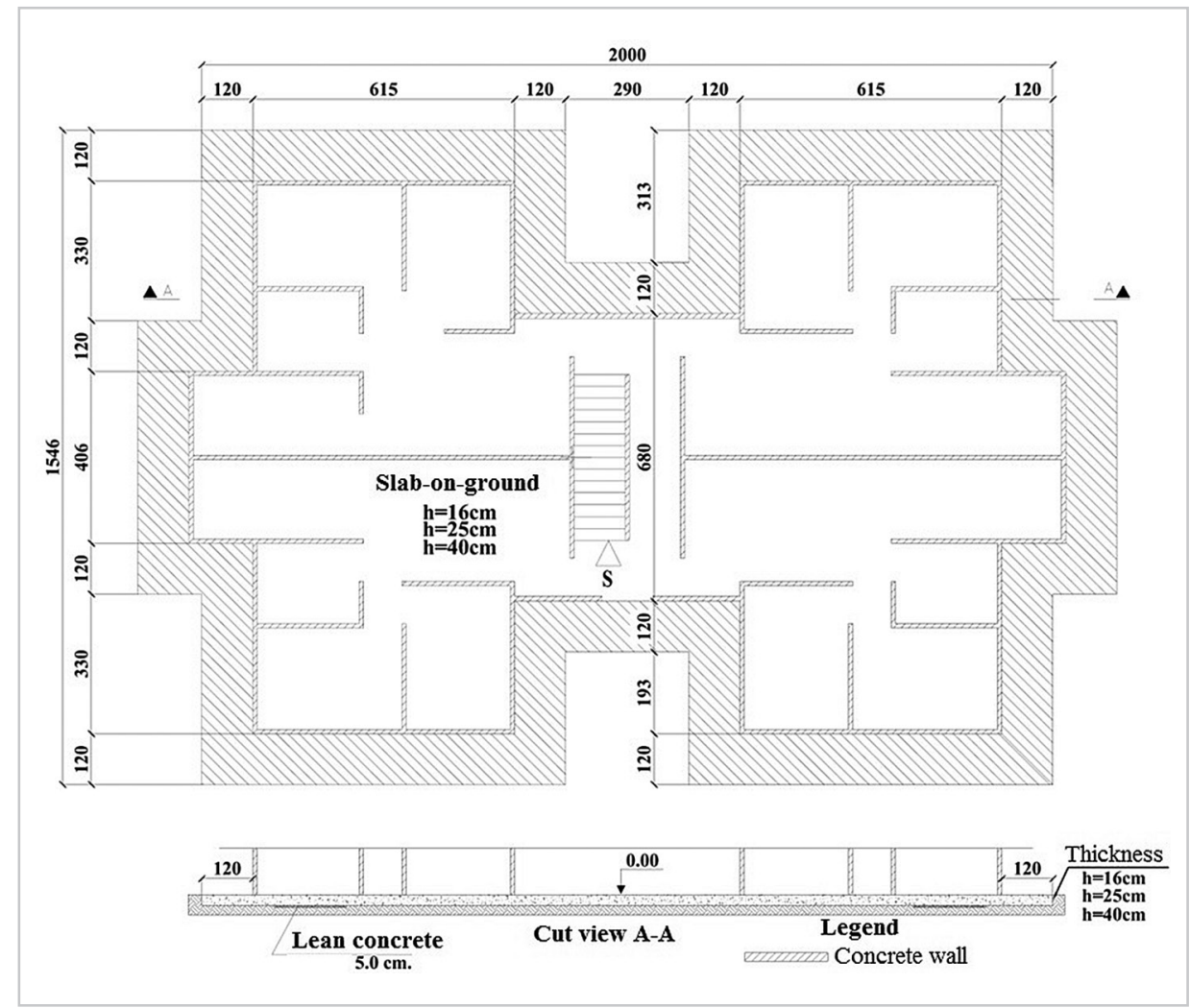

Figure 6 - Shape of the pilot building's slab-on-ground.

\section{Numerical modeling in FEM}

In order to measure the influence of the foundation's stiffness on the distribution of vertical stresses on the slab-onground, as well as its deformability, 3 (three) models were considered, with increasing variations in the slab-on-ground thickness. The analyzes were made with the following thicknesses: model $1(16 \mathrm{~cm})$; model $2(25 \mathrm{~cm})$ and model $3(40 \mathrm{~cm})$. The descent of vertical loads was made using the criterion of the group of isolated walls, considering the openings (doors and windows) as limiting elements of the groups, Figure 7. The slab-on-ground foundation was modeled with elements of bark $(20 \times 20) \mathrm{cm}^{2}$, where each element has 4 (four) nodes, each node having 6 (six) degrees of freedom, 3 (three) of translation and 3 (three) of rotation. The geotechnical massif was considered as a set of linearly spaced springs respecting Hooke's Law, therefore, a linear elastic regime. This hypothesis was assumed to be valid for this research, since the level of stress on the foundation is significantly lower than the load capacity of the soil (level of resistant tension). Furthermore, the active loading is mostly $(70 \%)$ static, which facilitates the predictability of its behavior.

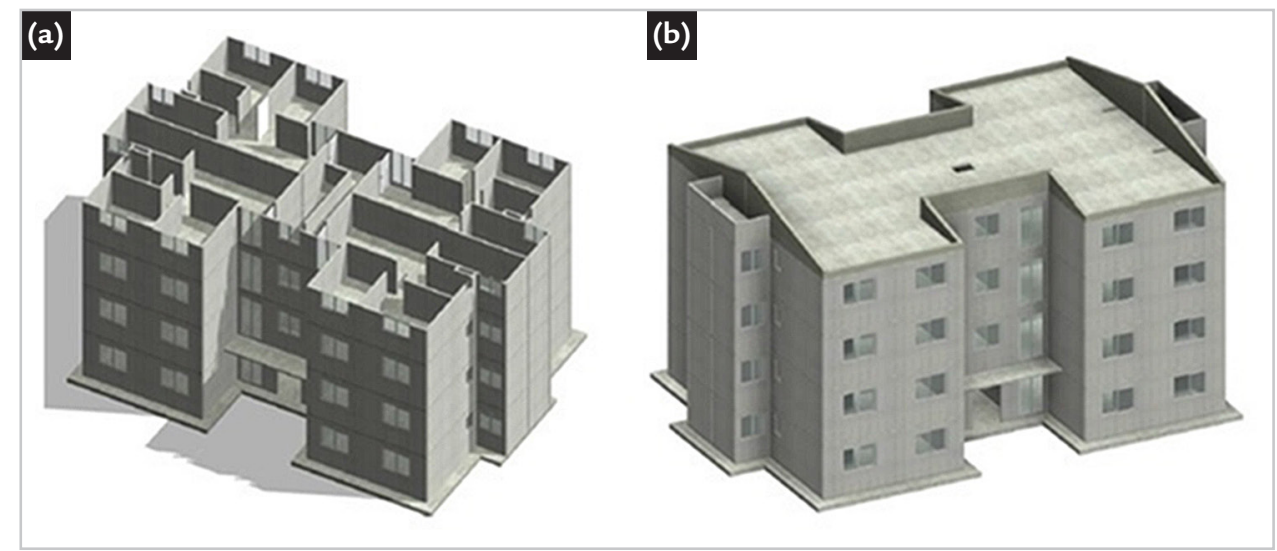

Figure 7 - Modeling of the pilot building: (a) without the roof slab, (b) with the roof slab.

The descent of vertical loads was made through the criterion of the group of isolated walls, where the openings, doors and windows, were considered as delimit- ing elements of the groups. Figure 8 shows the load map on the foundation structure. 


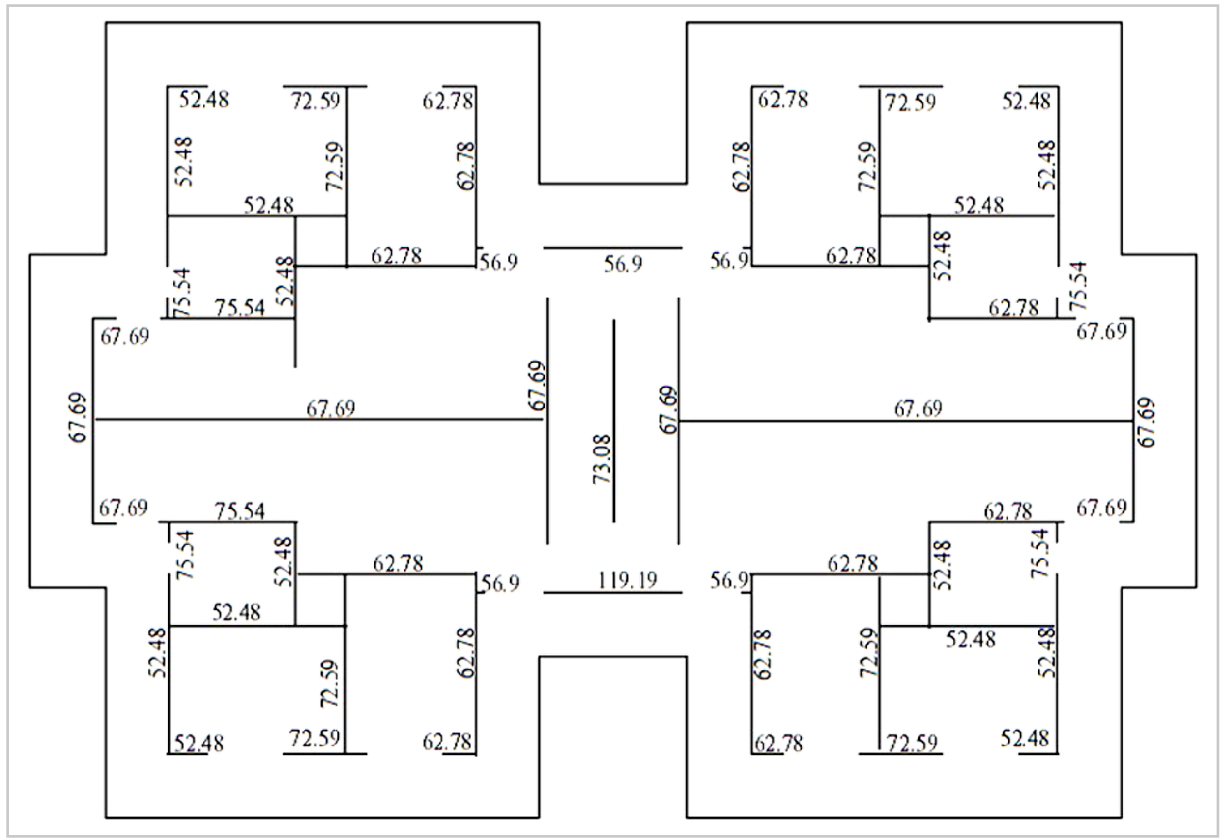

Figure 8 - Linear loads acting on the foundation $(\mathrm{kN} / \mathrm{m})$.

The FEM numerical/computational modeling was developed using Cypecad software (v. 2018).

\section{Results and analysis}

In order to parameterize the analysis of this research, the variables studied were: stress on the foundation, settlement in the slab-on-ground and reinforcement rate.
Figure 9 a), b) and c) show the results of stresses on the ground considering the slab-on-ground thicknesses of $16 \mathrm{~cm}, 25$ $\mathrm{cm}$ and $40 \mathrm{~cm}$, respectively. Figure $10 \mathrm{a}$ ), b) and c) show the results of settling on the foundation considering the slab-onground thicknesses of $16 \mathrm{~cm}, 25 \mathrm{~cm}$ and $40 \mathrm{~cm}$, respectively.

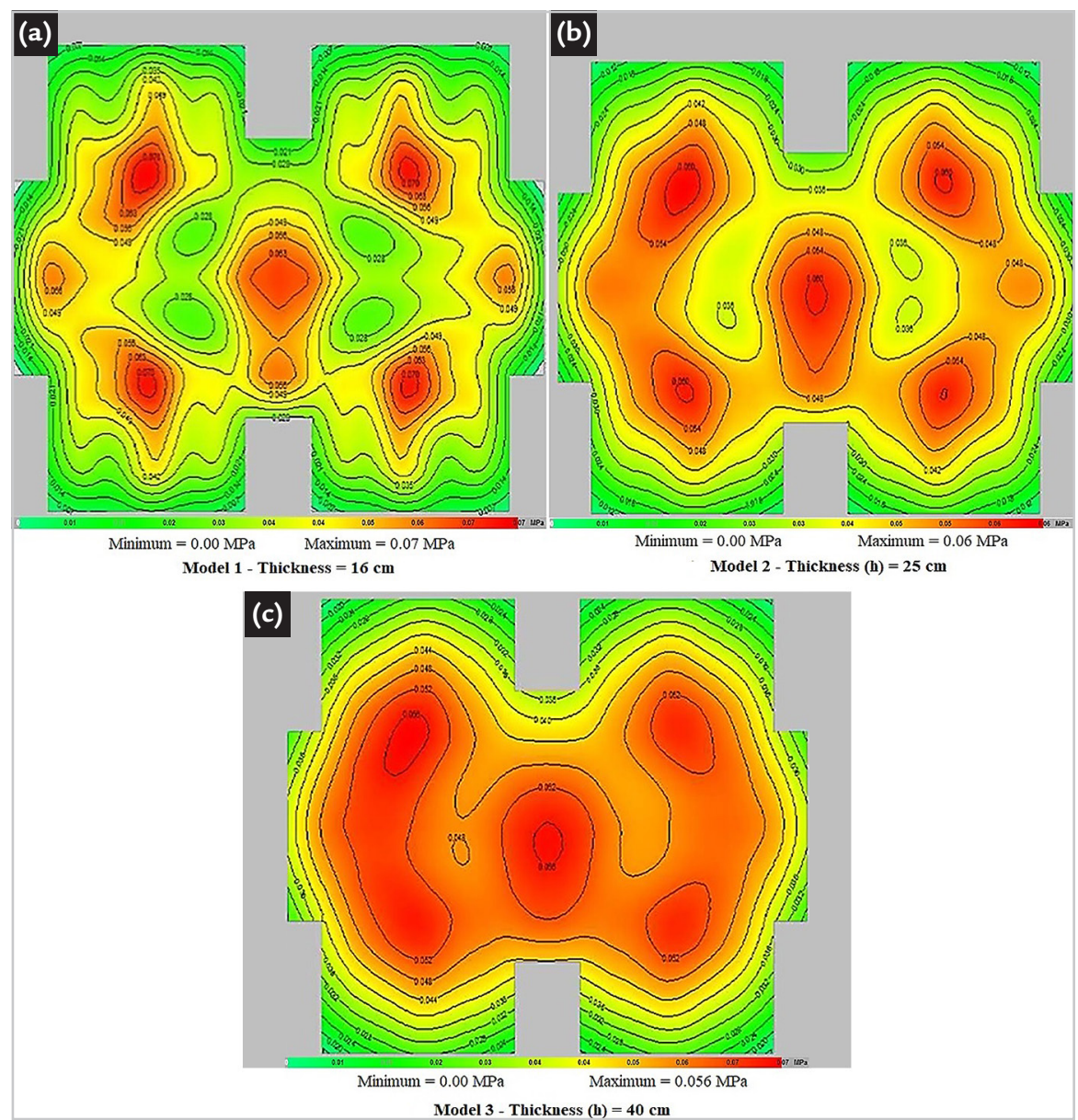

Figure 9 - Stresses resulting on the foundation (stresses in MPa): a) Model 1; b) Model 2; c) Model 3. 
Figure 9 allows us to state that as the slab-on-ground stiffness increases, there is a reduction in the magnitude of the maximum stress applied to the foundation soil. Another important point to note is that this reduction is accompanied by greater uniformity in the distribution of the mobilized stresses, as we gradually observe from Figure 9 a) to Figure 9 c).

Figure 10 allows to conclude situations related to those observed for the stresses applied to the foundation soil. That is, as the slab-on- ground stiffness increases, there is a reduction in the magnitude of the foundation settlements, as well as, this reduction is accompanied by a greater uniformity of settlements, as we gradually observe from Figure 10 a) to Figure $10 \mathrm{c}$ ).
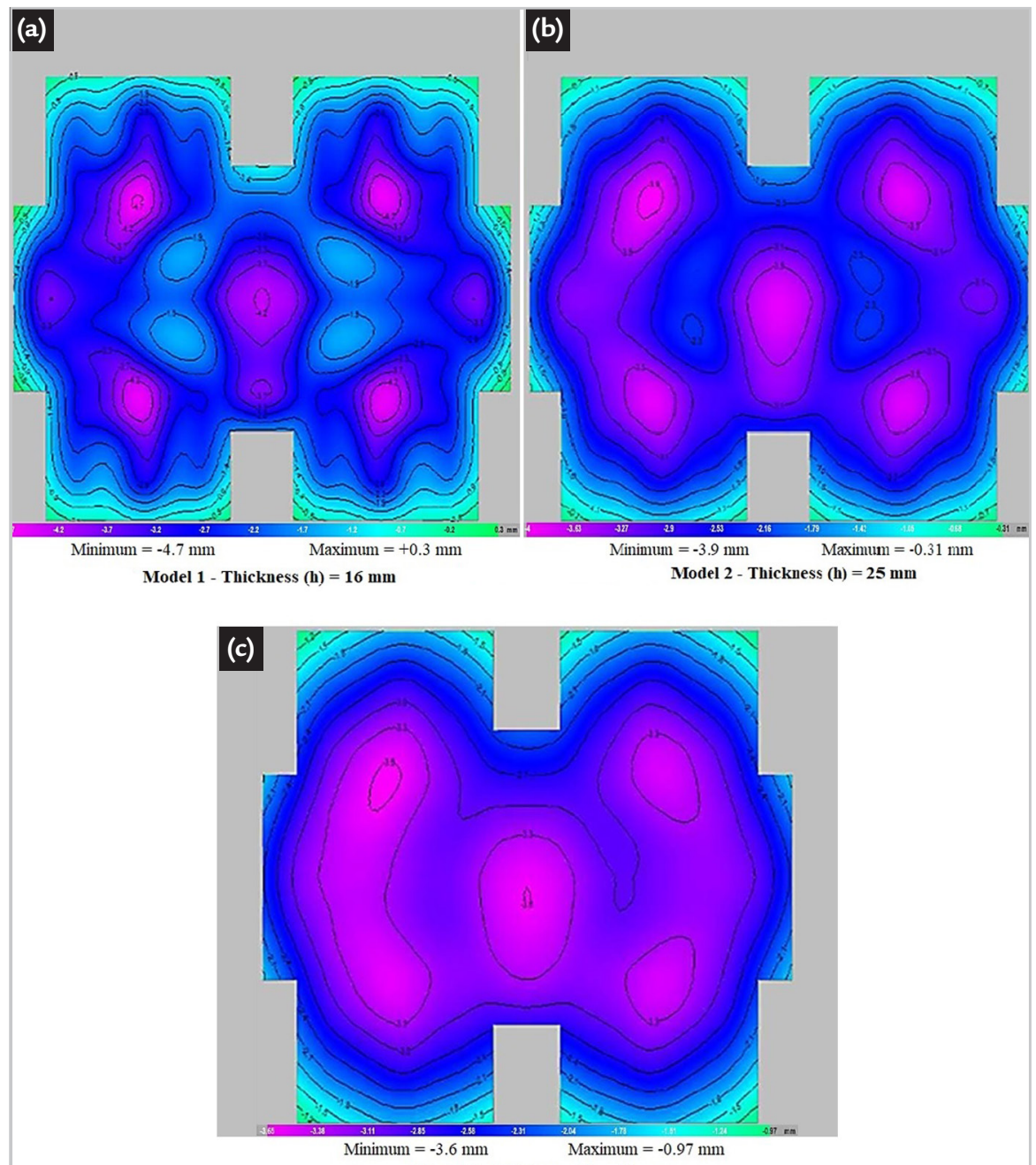

Model 3 - Thickness (h) $=40 \mathrm{~cm}$

Figure 10 - Settlement on the foundation (displacement in $\mathrm{mm}$ ): a) Model 1; b) Model 2; c) Model 3.

Table 1 presents the summary of the results obtained in the numerical model- ing performed. In this study, the stretches with vertical stress concentration (more loaded regions) and with more significant settlements were analyzed.

Table 1 - Summary of the results obtained in the numerical modeling.

\begin{tabular}{c|c|c|c|c}
\hline Model & $\begin{array}{c}\text { Thickness of slab-on-ground } \\
\mathrm{h}(\mathrm{cm})\end{array}$ & $\begin{array}{c}\text { Maximum vertical stress } \\
(\mathrm{MPa})\end{array}$ & $\begin{array}{c}\text { Settlement } \\
(\mathrm{mm})\end{array}$ & $\begin{array}{c}\text { Steel reinforcement bars ratio } \\
\left(\mathrm{kg} / \mathrm{m}^{3}\right)\end{array}$ \\
\hline 1 & 16 & 0.07 & 4.7 & 83.93 \\
\hline 2 & 25 & 0.06 & 3.9 & 46.70 \\
\hline 3 & 40 & 0.056 & 3.6 & 36.47 \\
\hline
\end{tabular}

Figure 11 shows the change in maximum stress on the foundation as a graph, as the slab-on-ground thickness is increased. It is noticed that this change is not linear, since the set of factors that influence this param- eter has a complex nature, therefore, not trivial. A similar analysis can be found in the settlement obtained in the foundation $(\mathrm{mm})$, Figure 12 and in the steel reinforcement bar ratio in the 3 models, Figure 13. The lat- ter tends to follow an exponential or polynomial relationship. Given the above, the importance of considering soil-structure interaction in structural and geotechnical engineering designs is emphasized. 


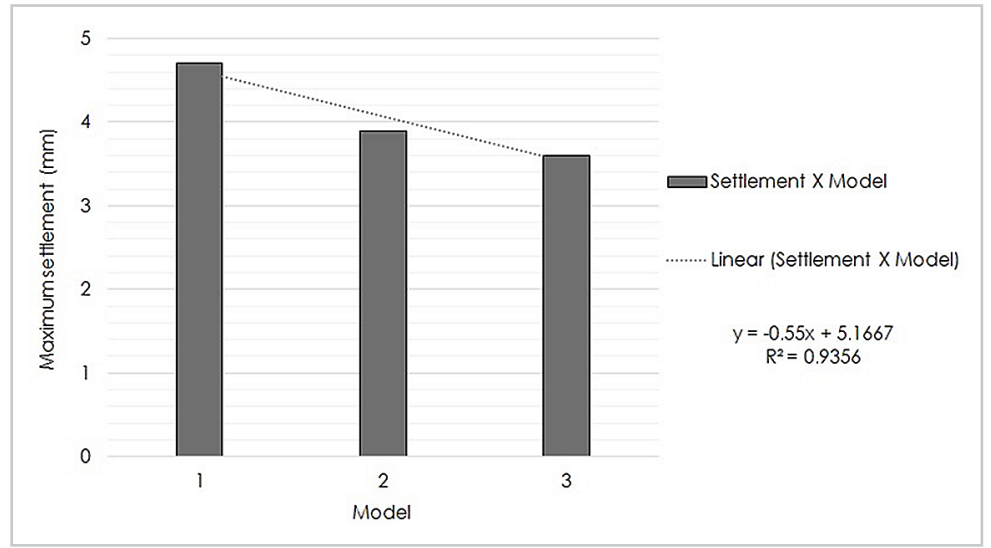

Figure 11 - Stress on the foundation $\mathrm{x}$ model analyzed graph.

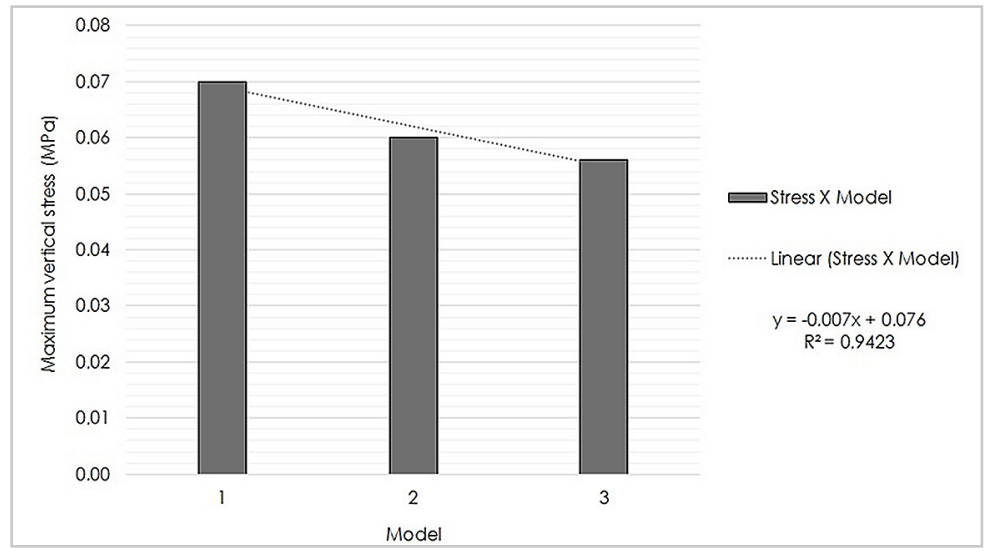

Figure 12 - Maximum settlement $x$ model studied graph.

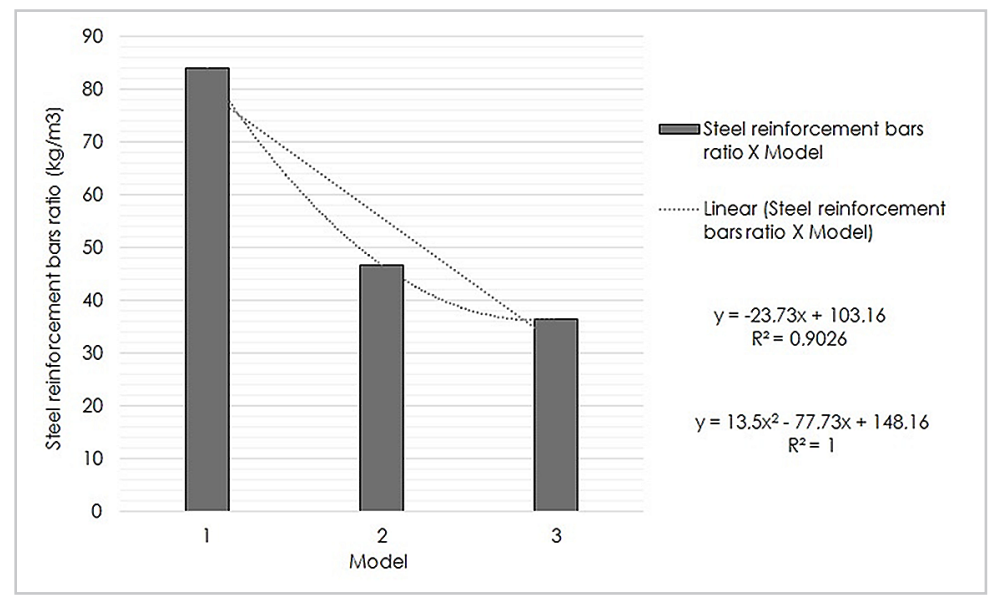

Figure 13 - Steel reinforcement bars ratio $\mathrm{x}$ model analyzed graph.

\section{Conclusions}

In this research, it was concluded that the SSI's consideration in the analyzed case study allowed a redistribution of the efforts along the structure as the slab-onground thickness (foundation structure) increased, being observed, thus, a relief of efforts in the more loaded central walls and additions to the walls of the periphery. Thus, regions with concentrations of tensions or settlements suffer relief, making it possible to have a better standardization of these variables and preventing that localized points of the foundation do not meet the design conditions, Ultimate Limit State
(ULS) and Service or Use Limit State (SLS). Finally, this consideration in the designs brings with it the design of more realistic and often more economical designs, as seen in terms of the steel reinforcement bar ratio, where consumption has decreased by almost half.

\section{Acknowledgments}

The authors would like to thank the Federal Center for Technological Education of Minas Gerais (CEFET-MG, acronyms in Portuguese) for supporting this research as well as Consmara Engenharia Ltda. for providing the data relevant to the case study. 


\section{References}

ANTONIAZZI, J. P. Interação solo-estrutura de edifícios com fundações superficiais. 2011. 138 f. Dissertação (Mestrado em Engenharia Civil) - Universidade Federal de Santa Maria, Santa Maria, 2011.

ASSIS, I. K. L.; PORTO, T. B. Processo de dimensionamento estrutural de pilares de concreto armado. Revista Multidisciplinar do Nordeste Mineiro, v. 1, n. 1., 2019.

ASSOCIAÇÃO BRASILEIRA DE NORMAS TÉCNICAS. ABNT NB-1: Cálculo e execução de obras de concreto armado. Rio de Janeiro: ABNT, 1940. 23 p.

ASSOCIAÇÃO BRASILEIRA DE NORMAS TÉCNICAS. ABNT NBR 6489: Prova de carga direta sobre terreno de fundação. Rio de Janeiro: ABNT, 2019. 2 p.

ASSOCIAÇÃ̃O BRASILEIRA DE NORMAS TÉCNICAS. ABNT NBR 16055: Parede de concreto moldada no local para a construção de edificações. Rio de Janeiro: ABNT, 2012. 35 p.

ASSOCIAÇÃO BRASILEIRA DE NORMAS TÉCNICAS. ABNT NBR 6118: Projeto de estruturas de concreto: procedimento. Rio de Janeiro: ABNT, 2014.

ASSOCIAÇÃO BRASILEIRA DE NORMAS TÉCNICAS. ABNT NBR 6122: Projeto e execução de fundações. Rio de Janeiro: ABNT, 2019.91 p.

BRAGUIM, C. T.; BITTENCOURT, N. T. Design of reinforced concrete walls casted in place for the maximum normal stress of compression. Revista Ibracon de Estruturas e Materiais, v. 7, n. 3, p. 498-533, 2014.

CARVALHO, F. L. Sistema construtivo em paredes de concreto para edifícios: dimensionamento da estrutura e aspectos construtivos. 2012. 112 f. Dissertação (Mestrado em Engenharia de Estruturas) - Escola de Engenharia, Universidade Federal de Minas Gerais, Belo Horizonte, 2012.

FARIAS, S. R. Análise estrutural de edifícios de parede de concreto com a incorporação da interação solo-estrutura $e$ das ações evolutivas. 2018. 243 f. Tese (Doutorado em Engenharia Civil) - Escola de Engenharia de São Carlos, Universidade de São Paulo, São Carlos, 2018.

MORAES, M. C. Estruturas de fundações. 3 ed. São Paulo: Editora McGraw Hill, 1981.

MORRISON, N. Interacción suelo-estructuras: semi-espaço de Winkler. Barcelona-Espanha: Universidad Politécnica de Cataluna, 1993.

PORTO, T. B. Estudo da interação de paredes de alvenaria estrutural com estruturas de fundação. 2010. $215 \mathrm{f}$. Dissertação (Mestrado em Engenharia de Estruturas) - Escola de Engenharia, Universidade Federal de Minas Gerais, Belo Horizonte, 2010.

PORTO, T. B.; FERNANDES, D. S. G. Curso básico de concreto armado. 1 ed. São Paulo: Editora Oficina de Textos, 2015.

PORTO, T. B.; MENDONCA, B. Q.; CARVALHO, L. S. G. Basic design requirements for structures subjected to dynamic action. Mecánica Computacional, Santa Fe, Argentina, vol. 31, n.13, p. 2547-2560, 2012.

PORTO, T. B.; SILVA, R. M. Vertical stress analysis in structural masonry buildings considering soil-structure interaction. In: NWC-NAFEMS WORLD CONGRESS 2011: A World of Engineering Simulation, Boston - EUA, 2011. Proceedings [...]. Boston-USA: NAFEMS, 2011.

RIBEIRO, C. M. Estudo numérico do comportamento tensão-deformação de fundação do tipo radier. $2017.197 \mathrm{f}$. Dissertação (Mestrado em Engenharia Geotécnica) - Universidade Federal de Ouro Preto, Ouro Preto, 2017.

SINGH, H.; JHA, J. N. Constitutive models for sustainable design of foundation systems. In: UKIERI CONCRETE CONGRESS - Innovations in Concrete Construction. 2014. Proceedings [...]. Punjab, India: UKIERI Concrete Congress, 2014. p. 2122-2133.

SIQUEIRA, D. C. Avaliação dos efeitos de $2^{a}$ ordem em pórticos planos de aço considerando apoios teóricos e interação solo-estrutura. 2019. 160 f. Dissertação (Mestrado em Engenharia Civil) - Centro Federal de Educação Tecnológica de Minas Gerais (CEFET-MG), Belo Horizonte, 2019.

TESTONI, E.; CORREA, M. R. S. Análise de interação solo-estrutura em edifício de paredes de concreto moldadas no local. Revista Fundações e Obras Geotécnica, v.6, p. 36-46, 2016.

TESTONI, E. Análise estrutural de edifícios de paredes de concreto por meio de pórtico tridimensional sobre apoios elásticos. 2013. Dissertação (Mestrado em Engenharia Civil) - Escola de Engenharia de São Carlos, Universidade de São Paulo, São Carlos, 2013.

VELLOSO, D. A.; LOPES, F. R. Fundações: critérios de projeto, investigação do subsolo, fundações superficiais, fundações profundas. São Paulo: Oficina de Textos, 2010.

Received: 29 July 2020 - Accepted: 7 December 2020. 